\title{
The Work Environment of Immigrant Employees in Sweden-a Systematic Review
}

\author{
Pinar Aslan Akay ${ }^{1}$ (D) Nader Ahmadi ${ }^{1}$ (D)
}

Accepted: 25 December 2021 / Published online: 13 January 2022

(c) The Author(s) 2022

\begin{abstract}
The aim of this systematic review was to summarize and synthesize research results focusing on the work environment of employees with an immigrant background in Sweden. We focus on the main conditions identified in the working environment of immigrant employees and how these conditions may affect their health and wellbeing. The concept of "minority stress" and the attachment theory are used to understand and interpret the findings. We systematically searched for literature published between the years of 1990 and 2020 in four databases, Web of Science, PubMed, SocIndex, and Academic Search Elite. We started the selection process by reading title and abstracts, then proceeded to read a selection of full-text studies and eliminated those that did not fulfil the inclusion criteria. We did a quality assessment on the full-text studies based on the MMAT-tool, and then performed a narrative synthesis of the results. The results show that immigrants experience several stressors in their work environment, including physical, psychological, and social risks. These risks are, among other things, associated with the nature of the jobs that immigrants are overrepresented in, with minority-related stressors such as discrimination, harassment, and threats on the basis of ethnic background, and with the lack of social support from managers and colleagues. Results also highlight beneficial factors in the immigrants' working environment and show the importance of a supportive, inclusive, and empowering management. Our main conclusion is that Swedish workplaces need to introduce more active measures to raise awareness of and combat workplace discrimination, work harder to promote inclusion at the workplace, and eliminate physical, psychological, and social health hazards specific to immigrant employees. The leadership and management have an important role to play here, as does the employees' trade unions and its special functions.
\end{abstract}

Keywords Work environment · Labor market - Working conditions · Workplace discrimination $\cdot$ Immigrant $\cdot$ Integration

Pinar Aslan Akay

Pinar.aslan@mynak.se

Extended author information available on the last page of the article 


\section{Introduction}

In many ways, participating on the labor market is essential for a person's health. It provides economic security, an arena for social interaction, and can also help foster a sense of self-fulfilment (cf. Ahonen et al., 2007; Sterud et al., 2018). Nevertheless, working conditions can have both positive and negative impacts on people's physical, mental, and social health. The negative effect of an inadequate working environment on employees' health and well-being has been extensively highlighted within work environment and health research (see, e.g., de Vos \& Kirsten, 2015; Karasek, 2008; Pien et al. 2019; Rasmussen et al., 2011; Stansfeld \& Candy, 2006; Shen \& Slater, 2021). Workplace health risks and poor working conditions often breed mental and physical health problems, leading to, e.g., sickness absence or even occupational fatalities (Takala et al., 2009).

In this study, the concept of work environment refers to a number of organizational and social conditions, both physical and psychosocial, that may have an impact on the health and well-being of employees. Problems in the physical work environment include, among other things, heavy physical and monotonous work assignments, harming/non-ergonomic physical work positions, and insufficient visual ergonomics (Kolstrup, 2012; Lund et al., 2006). Organizational and social conditions that have detrimental effects on employees' health and well-being may for example be inappropriate skill requirements and workload (Canivet et al., 2013), insufficient resources for managing the tasks and lack of control over the work process (Harvey et al., 2020), poor social support and collaboration with colleagues (Lowe et al., 2020), bullying and discrimination (Okechukwu et al., 2014), and shortcomings in management and governance (AFS, 2015:4).

These problems have shown to be even more aggravated in the case of immigrant workers across Western countries. As shown by Sterud et al. (2018) in a systematic review focusing on the occupational health of immigrants in Europe and Canada, bullying and perceptions of workplace discrimination are more prevalent among immigrants as compared to natives. The same applies to the risks of workplace injuries and disadvantages in terms of self-reported health and mental distress.

This also seems to be the case in Sweden (Svensson et al., 2015). For example, immigrant employees in the agricultural industry are exposed to more harmful working conditions, including an increased accident risk, exposure to chemicals that are harmful to health, threats and violence, discrimination, long working hours, and lower pay compared to the native-born population.

According to Statistics Sweden (2019), 1048000 immigrants in Sweden are economically active, whereas 955000 of them are employed. Although a large and increasing share of the working population in Sweden is foreign-born, relatively few studies have focused on their working environment. Identifying and eliminating risk factors in immigrants' working environment contributes to a successful labor market integration. Risk factors can deteriorate the health of immigrant workers in a long-term manner and eventually lead to an early retirement and social exclusion (cf. Dunlavy \& Rostila, 2017). 
To our knowledge, there are no systematic reviews focusing on the working environment of immigrant employees in Sweden today. The Swedish case may be interesting in an international perspective, against the background of the long tradition of unionization and collective bargaining and an extensive legislation on work environment and anti-discrimination acts, in addition to a relatively large volume of receiving immigrants in recent decades. Traditionally, trade unions have played an important role for immigrant workers in Sweden, contributing to labor market inclusion for many newly arrived immigrants (Boräng et al., 2020). As in other countries with strong union movements, the trade unions in Sweden have insisted on narrowing the rights gap between native and immigrant workers over the years (Knocke, 2000). Nevertheless, many inequalities persist for immigrant employees at the Swedish labor market, and more knowledge is required to enhance an understanding of mechanisms involved in these inequalities. A more comprehensive picture of immigrant employees' working environment can be an important steppingstone to further studies in the area.

A systematic review was chosen as the design of the current study to identify and summarize the findings of studies published between 1990 and 2020 dealing with the working environment of immigrants in Sweden. In this review, an immigrant employee is defined as someone who is foreign-born and who actively participates in the labor market of the host country. We chose not to look at the country of origin of the immigrants, since there is a lack of data in respect to this in many studies. However, where studies report on this, we have taken immigrant background into account (e.g., as Western or non-Western background). Other aspects, such as religious belonging, migrant status, and length of stay in Sweden, are also interesting factors but we have considered them to be beyond the scope of this review.

The overall aim of this systematic review was to summarize and synthesize existing research results dealing with the work environment of immigrant employees in Sweden. This was investigated through the following two research questions:

1. What main physical and psychosocial work conditions are identified in studies about the work environment of immigrant employees in Sweden?

2. How, according to these studies, do these conditions affect the health and wellbeing of immigrant employees in Sweden?

\section{Work Stressors and Their Impact on the Health and Well-Being of Immigrant Employees}

This review employs the concept of "minority stress" and the attachment theory to analyze and interpret the results. In this section, we will provide an introduction of these two perspectives, and explain how they can enhance the understanding of immigrants' work environment and its impact on their health and well-being.

Like other minorities, people with an immigrant background may experience so-called minority stress at work, which, according to Meyer's (2003) definition, is "excess stress to which individuals from stigmatized social categories are exposed 
as a result of their social, often a minority, position" (p. 675). Meyer (2003) initially developed the concept of minority stress to study stressors and coping mechanisms of members of the LGBT community and focused on the impact of such stressors and coping strategies on their health outcome. Since then, many scholars have used the minority stress model to show how marginalized groups of society face unique minority-related stressors that negatively affect their physical and mental health (Arbona \& Jimenez, 2014; Botha \& Frost, 2020; Frost et al. 2015; Lehavot \& Simoni, 2011).

Extending Meyer's minority stress model to studying immigrants, one can assume that stress processes, including experiences of prejudices, discrimination, and social exclusion at work, can have a significant effect on the health outcome of immigrant employees. For example, Valentín-Cortéz et al. (2020) found that undocumented latinx immigrants experienced unique stressors related to their minority identity, leading to feelings of anxiety and a deteriorated psychological health. The sources of these unique stressors were, among other things, fear of being deported and discrimination, caused by a growing anti-immigrant social environment. In a similar vein, Jung et al. (2007) found a positive association between experiences of discrimination and depressive symptoms among international students in the USA.

However, research also shows that minority members are active agents who develop strategies to deal with such stressors. Saasa (2019), for example, found that African immigrants in the USA cope with discrimination and social exclusion by using active problem solving, religion, or by seeking support from others. Moreover, Showers (2015) found that African women use a coping strategy of distancing themselves from work areas with a higher risk of being discriminated against. These findings suggest that minority group members are not only passive recipients of minority-related stressors but that they also respond to negative or stressful situations in different ways.

Social exclusion, in particular, can be experienced as a huge stressor, since social support at work is important for the health and adjustment of workers (Nelson \& Quick, 1991). Attaching emotional bonds with co-workers can mitigate the negative effect of work-related stress (Karasek \& Theorell, 1990) and decrease the risk of burnout (Houkes et al., 2003). These findings are underlined by the influence of "attachment theory" in organizational research, where many scholars demonstrate the association between social relations at work and mental health, job adjustment, and job satisfaction (Yip et al., 2018; Littman-Ovadia et al., 2013; Tziner et al., 2014; Schirmer \& Lopez, 2001). The attachment theory, initially developed by Bowlby (1982) and Hazan and Shaver (1990), is focused on the attachment behavioral system, a psychological program that governs the support-seeking behavior of individuals in distressed situations. The attachment behavioral system is triggered by events that result in feelings of insecurity, stress, and threat, and deactivated when receiving social support that reinstalls a sense of safety (Mikulincer et al., 2002).

In a workplace setting, scholars have found an association between managerial leadership and perceived stress, self-rated health, and the frequency of being on sick leave due to overstrain (Westerlund et al., 2010). An absent or inconsistent leadership support may activate more insecure, sensitive, and anxious types of behavior among employees (Hudson, 2013; Wu et al., 2014). In contrast, managerial support, 
including acknowledging employees' contributions, being attentive to their health, and continuously providing feedback, has been found to foster more resilient and resourceful employees (Kuntz et al., 2017).

\section{Methods}

During October 2020, we searched systematically for the period 1990-2020 in the four databases Web of Science, PubMed, SocIndex, and Academic Search Elite. Literature found through these databases was then imported to Endnote for title and abstract screening. Once irrelevant articles and duplicates were removed, a second screening was conducted, including a full-text reading of the articles. The reference lists of these full-text articles were also screened for additional relevant articles. To map out the number of studies identified, included, and excluded, we used the PRISMA flow diagram (Fig. 1) for documentation during the screening of studies.

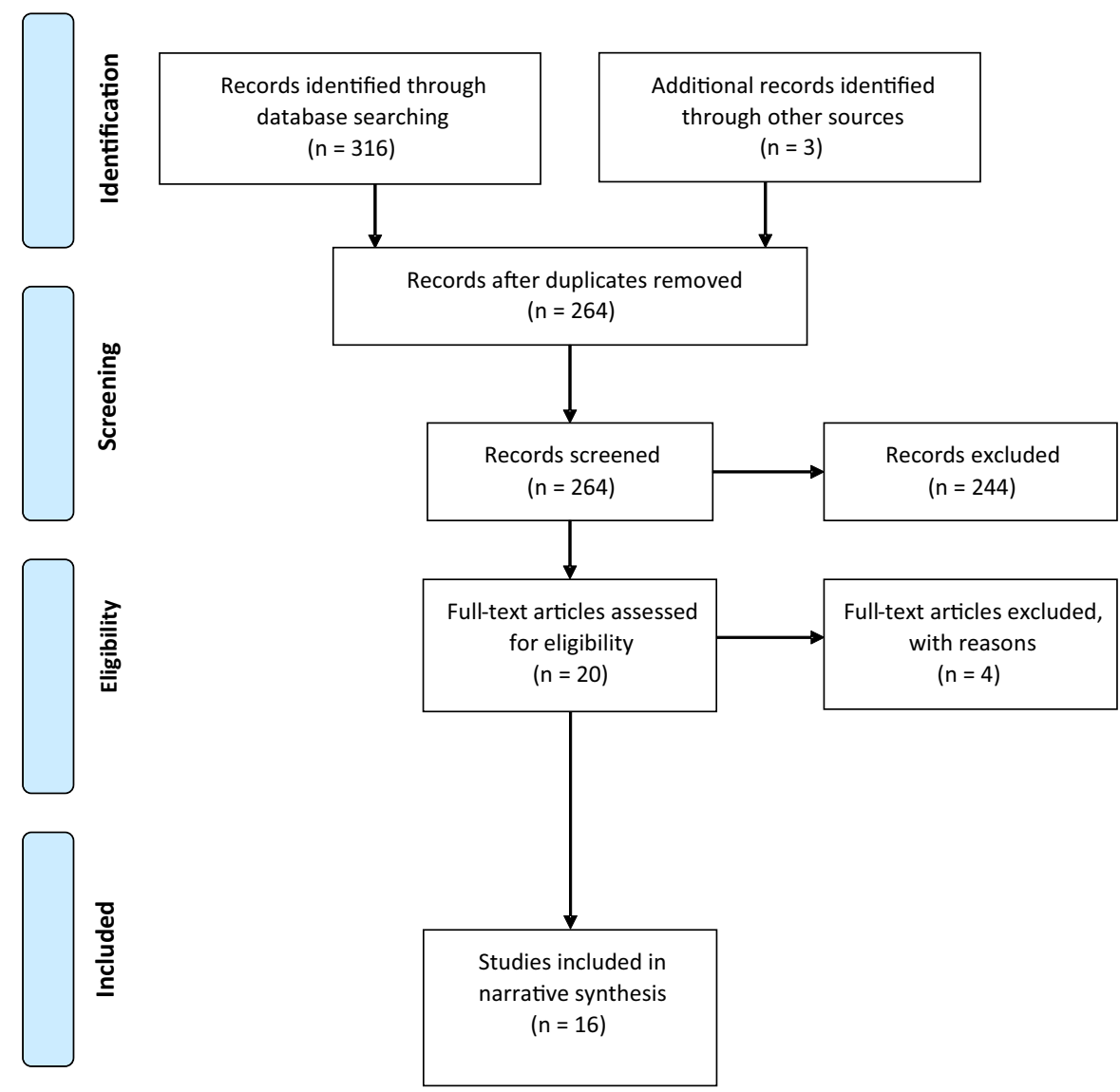

Fig. 1 The PRISMA 2009 flow chart 


\section{Search Strategy}

To improve the focus and searches for the study, the PICO tool (see, e.g., SBU, 2017) was employed and resulted in the following outline: (P)opulation: immigrant workers in Sweden; (I)ntervention: work environment and working conditions; (C)omparison: where studies report on outcomes in both migrants and native workers, native workers will be the comparator - otherwise, comparison is not applicable; and (O)utcome: occupational health (mental, physical, or social), occupational well-being, occupational exposure, and work-related risks.

The literature searches were based on three search terms: Work environment, Immigrants, and Sweden. These three terms were used to find relevant key words, including synonyms and various types of spelling. To find more relevant search terms for our database searches, we complemented the list of key words by looking at title/abstracts of key articles and by searching the Cochrane library for other reviews close to our subject area.

The number of studies found in Web of Science was 26, in PubMed 195, in SocIndex 23, and in Academic Search Elite 72. Three additional studies were found by searching the reference lists of relevant full-text articles. After removing all duplicates, 264 records remained (see Fig. 1 for more details).

\section{Inclusion/Exclusion Criteria}

While reading the titles and abstracts, all articles that did not mention aspects related to working environment, immigrant populations, and in which the empirical data was not conducted in a Swedish context were excluded. All articles that were assessed as relevant or potentially relevant were read by one of the authors. Articles that did not fulfil the inclusion criteria were excluded (see Appendix Table 1). Moreover, pilot studies and reviews were excluded (although the reference lists of reviews were scanned for relevant papers that had not appeared in the database searchers). For inclusion, the articles had to meet the following criteria:

1. The study included and reported data for immigrant workers (foreign-born individuals participating in paid work).

2. The study focused directly on working environmental issues, e.g., working conditions, occupational health or exposures, and job satisfaction, of immigrant workers.

3. The study is based on empirical data from the year 1990 and onwards.

4. The study focused on Swedish workplaces.

5. The study was peer-reviewed.

6. The study was written in the Swedish or English language. 


\section{Quality Assessment}

Although the included studies here were all peer-reviewed, it is still relevant to make a critical assessment of the quality of relevant studies (cf. Gough et al., 2012). Since we included both qualitative and quantitative studies in this review, and since some of the relevant studies used a mixed-methods approach, we decided to employ a tool that facilitates a quality assessment of various methodological studies, i.e., the Mixed Methods Appraisal Tool (MMAT). The MMAT checklist (Hong et al. 2018) allows for a quality assessment of five types of original studies (see Appendix 3 for details of how the included studies were assessed): qualitative studies, randomized and non-randomized quantitative studies, descriptive quantitative studies, and mixed-method studies (Hong et al., 2018; Pace et al., 2012). This review only includes qualitative, quantitative descriptive, and mixed-method studies, and so we have only applied questions relevant for these study types to assess the quality of the included studies. Depending on whether the answers to the screening questions were positive or negative, the studies were assessed as being of either low, medium, medium-high, or high quality. The quality of the studies was assessed according to the following logic:

Answer to 0 questions is no/can't tell = High quality

Answer to 1 question is no/can't tell=Medium-high quality

Answer to 2 questions is no/can't tell = Medium quality

Answer to 3-5 questions is no/can't tell= Low quality

All 16 studies that made it to the quality screening were assessed as having either medium ( $n=3$ studies), medium-high ( $n=6$ studies), or high quality ( $n=7$ studies), and so were all included in the review. The overall high quality of the studies was most likely because the database searches only included peer-reviewed studies.

\section{Data Analysis}

The included studies were categorized in an overview (see Appendix Table 2), including information about author/title, aim, research design/method, and sample size/sample characteristics. Thereafter, a second reading of the full-text articles focused on results, discussion, and conclusions to identify themes. The results were finally formed into four themes based on the most prominent patterns that emerged from the findings. These themes were (1) discrimination and social exclusion at the workplace, (2) work-related physical and psychosocial risks, (3) inclusion at the workplace, and (4) the labor market segregation of immigrants.

As mentioned before, the included studies were of different methodological designs, 13 of the studies were of various quantitative designs, one had a qualitative, ethnographic approach, and two used a mixed-methods approach. As argued by Harden and Thomas (2005), including different study types in a review gives strength to the conclusions drawn by the review, since systematic reviews are focused on a set of questions rather than the used methodology of studies. Most 
researchers would, however, agree that it is a challenge to synthesize evidence relying on research that uses different types of methods and designs (cf. Rodgers et al., 2009). Here, we chose to present the results using a narrative synthesis (cf. Arai et al., 2007) in which the results from all study types are analyzed, summarized, and described in text (Popay et al., 2006). This form of synthesis has been chosen since it facilitates a coherent description and discussion of the research, while also allowing for a common presentation of results deriving from several study types.

\section{Results}

Sixteen studies in total were included in this systematic review. Seven of the included studies had a cross-sectional design using survey data. Three had a panel design with at least two waves of data, which enabled comparisons over time. Three had an explanatory quantitative design, focusing on studying the relationship between two or more variables. Two had a mixed-methods approach and applied a sequential explanatory design where qualitative data was used to provide a deeper understanding of formerly collected quantitative data. Finally, one of the studies had an ethnographic, qualitative design and used participatory research and qualitative interviews to collect data.

\section{Discrimination and Social Exclusion at the Workplace}

One main pattern that emerges from the findings of this review is that immigrant workers perceive and experience discrimination at Swedish workplaces. Experiences of discrimination in the workplace are present for both male and female immigrants, and most prominent for people of a non-Western background, i.e., from countries outside of Northwest Europe and North America. A study using data from a survey of people employed in elderly care work by Malmö municipality in Sweden compares perceptions of discrimination among immigrant and native-born workers in Sweden, and finds that immigrants from non-Western countries in particular perceive higher degrees of discrimination in the workplace (Behtoui \& Neergaard, 2009).

In a cross-sectional study examining work-related health factors for females (Akhavan et al., 2007), it was demonstrated that the perception of discrimination at work was three times higher for female immigrants in comparison to female native-born workers. Thus, female immigrants experience a unique form of discrimination related to their immigrant background in excess of the gendered discrimination faced by women in general on the Swedish labor market. These results are congruent with the basis of the minority stress model, presuming that some stressors are unique or magnified for minority group members (Meyer, 2003).

Workplace discrimination can have an important impact on the career opportunities of immigrant employees. In a more recent study, using a mixed-methods approach, Behtoui et al. (2020) find that discrimination of immigrant workers 
led to exclusion from more powerful social networks at the workplace, and that immigrant workers thus have less access to valuable resources, leading to drawbacks in both occupational status and wages. These findings are in line with those of Akhavan et al. (2007), who showed that immigrants more often report a lack of opportunities in discussing wages and to upgrade their skills.

Because of frequent experiences of social exclusion and increased exposure at the workplace, immigrant workers have higher turnover intentions than nativeborn. Rosmond et al. (1996) report that immigrant workers were more often dissatisfied with their current work and colleagues and more frequently wanted to change their jobs. These findings demonstrate the importance of forming positive relations with others at work and is in line with the attachment theory which underscores that the absence of social support at work can be a significant source of stress. Moreover, this form of stress can cause individuals to develop various coping strategies, here exemplified by the desire to change one's job.

Dissatisfaction with colleagues was also reported in another study from the same authors evaluating the possible impact of work-related stressors on psychiatric health in immigrants compared to native-born Swedes (Rosmond et al., 1998). The findings further strengthen the assumption that absent or negative relations with co-workers are more frequently experienced by immigrant workers and can be detrimental for their health and well-being. Sundquist et al. (2003) show that immigrants with a low work-related social support (e.g., being able to interrupt work to talk to co-workers or meeting co-workers outside the workplace) ran a higher risk of long-term illness. From a minority stress perspective, these results indicate that work-related stressors, such as social exclusion at work, can have a long-term negative impact on the physical and psychological health of immigrant employees.

\section{Work-Related Physical, Psychological, and Social Risks}

Since non-Western immigrant workers are overrepresented among those employed in manual, unskilled jobs (Dunlavy et al., 2016), they also experience high levels of physical demands at work (Dunlavy \& Rostila, 2013). Therefore, some workplace physical and psychological risks are due to labor market segmentation, i.e., that immigrant workers generally do not participate at the labor market at the same conditions as native-born and are thus confined to immigrant-dense, low-status jobs (cf. Urban \& Slavnic, 2008). They more often tend to be employed in low-skilled jobs (Dunlavy \& Rostila, 2013; Ilsøe, 2016; Slavnic \& Urban, 2018), generally have lower occupational status (Behtoui et al., 2020), are more often in temporary employment (Akhavan et al., 2007), are more frequently working part-time (Ilsøe, 2016), and are overrepresented in jobs where they work long hours for lower pay in comparison to native-born (Slavnic \& Urban, 2018). Some workplace risks in these low-skilled jobs are due to the nature of the job and experienced by people employed in that sector in general, while other risks are uniquely experienced by immigrants and related to their immigrant background. 
However, work-related physical and psychological risks are not confined to the unskilled/low-skilled job market. These risks can also be present for immigrants working in high-skilled professions. Workplace risks in high-skilled sectors are, however, seldomly related to the nature of the job, but rather to the immigrant background of employees. For example, Eneroth et al. (2017) showed that general practitioners with a foreign-born background experienced threats or violence from patients to a significantly higher degree than native-born general practitioners ( $22 \%$ compared with $3 \%$ ). These forms of threats and violence were often specifically related to their immigrant background as racist and xenophobic displays. Thus, immigrants who work in a majority context and in high-skilled professions can also experience unique physical risks related to their minority background. Eneroth et al. (2017) also showed how the general practitioners with an immigrant background had higher levels of turnover intentions due to these threats and violent attacks from patients. These results are in line with the minority stress perspective, explaining how minority members can develop coping strategies to deal with negative experiences at the workplace, such as changing one's job or workplace.

Moreover, a study conducted by Rosmond et al. (1996) demonstrates differences in psychosocial status associated with the working environment between immigrant and native-born workers in Sweden. Rosmond et al. (1996) compared native-born male workers with immigrant male workers in Gothenburg, Sweden, and showed that immigrants generally experienced higher degrees of psychological distress than did natives. The immigrant workers were more often in shift-work, less satisfied with their work, dissatisfied with co-workers, and felt that they had less influence on their work situation.

In another study, Rosmond et al. (1998), using the same dataset, reported that immigrant male workers were less affected by their working conditions, except for dissatisfaction with co-workers which was an important work-related stressor. It is important, however, to bear in mind that the sample used by Rosmond et al. (1996, 1998) mainly consisted of Scandinavian immigrants, largely from Finland. More recent studies report that immigrants from non-Western countries are at particular risk of being negatively affected by work-related psychosocial stressors, for example, because of a higher degree of over-education (Dunlavy et al., 2016), financial strain, and mental distress (Sundin et al., 2011). These differing results indicate that the outcome of studies from the twentieth century can be significantly different from those of the twenty-first century, which, among other things, is due to the ethnic variety of the immigrant population of Sweden during these time eras.

Psychosocial risk factors in the working environment may have many long-term negative effects for immigrants. For example, psychosocial distress at the workplace associated with high burnout scores has been reported as a particular risk for female immigrants in Sweden. Using a sample of 6,000 randomly selected women from the general population, of which 3,591 participated, Soares et al. (2007) showed that women with high burnout scores were more often foreign-born. However, according to the authors, this was not due to their foreign-born status per se, but rather associated with, e.g., being on sick leave more often, experiencing financial strain, lower control, and low social support at work. Consequently, when Sundin et al. (2011) controlled for other factors, such as distress, being foreign-born was no longer an 
important factor for high burnout scores. This suggests that foreign-born women, in comparison to their native-born counterparts, are more often distressed, and experience negative socioeconomic aspects related to their working environment, which in a long-term perspective leads to higher burnout scores.

\section{Aspects Fostering a Beneficial Working Environment for Immigrant Employees}

Only a few of the studies identified for this review deal with factors that promote a positive working environment for immigrant employees in Sweden. One important beneficial aspect in respect to this is good leadership at the workplace. According to Eneroth et al. (2017), factors that positively affected the working environment of immigrant employees were control over work pace, i.e., having the ability to control the amount of work assigned to oneself, being able to decide when to take a break, and setting one's own work hours. However, Eneroth et al. (2017) also found that immigrant workers who feel that they are well taken care of in the organization, rewarded for a job well done, and where the employer is engaged in their health and well-being have a higher propensity to stay at their workplace. These findings are in line with the basis of the attachment theory, underlining that people who feel supported by their managers are more inclined to find ways to cope with other stressors at work, and thus stay put at the workplace.

Another aspect that positively affect immigrants' job satisfaction is the ethnic composition of co-workers at the workplace. Bygren (2004) found that immigrants have a greater tendency to stay at workplaces where relatively many immigrants work. This is especially the case for non-Western immigrants, which Bygren (2004) interprets as associated with perceptions of social inclusion; the more different a person feels from the majority-population, the higher the tendency to stay put at workplaces where others are perceived as different as well. In line with the attachment theory, these findings underscore how crucial a sense of social belonging is for job satisfaction, and that many immigrant employees may have a more natural way of experiencing such belongingness among other immigrant employees.

There are also results demonstrating how social belonging can emerge for immigrant employees in workplaces with many native-born co-workers, through the use of certain strategies employed by the immigrant workers. Nelson (2014) shows how immigrant employees in Swedish workplaces use joking and swearing, among other things, to foster good relations at work. Studying industrial and office workers at a major company in Sweden, she discovers that immigrants learn workplace culture and employ several techniques, such as handling small talk, humor, compliments, and greetings to create good relations at the workplace, which foster their workplace integration. According to Bowlby (1982), the attachment behavioral system is triggered by situations or events that expose a person to physical or psychological threat, here exemplified by entering a workplace where there is a risk of being socially excluded. Such threats trigger responses that focus on fulfilling one's innate attachment needs, for example, by seeking other people's support. Nelson's (2014) study exemplifies this process in terms of using language to create a sense of belonging and to form emotional bonds to one's co-workers. 


\section{Discussion and Conclusions}

The aim of this systematic review was to summarize and synthesize research results dealing with the working environment of immigrant employees in Sweden. We focused on two main aspects. First, what main physical and psychosocial working conditions are identified in studies about the working environment of immigrant employees in Sweden? Second, how, according to these studies, do working conditions affect the health and well-being of immigrant employees in Sweden? To reach a better understanding of the results, we used the concept of "minority stress" and the attachment theory to interpret our findings. The minority stress perspective has mostly been used to explain how members of the LGBTQ community face minorityrelated stressors which negatively impact their health and well-being. In this review, we have demonstrated how such stressors are also uniquely experienced by immigrants at the workplace.

The review shows that immigrant employees are generally more exposed to several physical hazards and work under poor psychosocial conditions in their working environment as compared to their native-born colleagues in Sweden. This result is in line with the results of reviews focusing on immigrant employees in Western countries (e.g., Ahonen et al., 2007; Wang \& Jing, 2018). The unprivileged work conditions of the immigrant employees are, to some extent, due to the nature of the lowskilled jobs that immigrants are overrepresented in, e.g., heavy, monotonous work for longer hours and lower pay, which is often considered as a characteristic of a segmented labor market where many immigrants are forced into low-status jobs (cf. Urban, 2013; Wang \& Pandit, 2007).

Some researchers have depicted labor market segmentation as a problem for societal integration in general, since working in immigrant-dense workplaces provides immigrant employees with few chances to form relations with native-born people (cf. Ejrnæs, 2008). Our review shows that labor market segmentation also means an increased vulnerability for risks in the working environment which are detrimental for health and well-being. In the long run, this may lead to an early exit from the labor market for immigrant employees, due to higher frequencies of sick leave or early retirement (cf. Dunlavy \& Rostila, 2017). Ethnic segmentation in the labor market has, among other things, been attributed to the unequal opportunity structures of ethnically homogeneous networks and discrimination in recruitment (cf. Meyer \& Vasey, 2020). Moreover, the employment protection legislation for fixedterm and temporary employment contracts in Sweden has weakened in recent decades. While the temporarily employed face smaller risks than the unemployed, the weakened employment protection legislation for this group put them in a marginalized position vis-à-vis the permanently employed, thus paving the way for a segmented labor market (Svalund \& Berglund, 2018).

Moreover, the current review also shows that physical and psychosocial work conditions that negatively influence the health and well-being of immigrant employees also exist in high-skilled jobs where many of the employees are native-born. The findings highlight an increased exposure to minority stress among immigrant employees, e.g., experiences of discrimination, threats, and violence uniquely 
experienced by immigrant employees. In contrast to the risks that derive from labor market segmentation, minority-related stressors have nothing to do with the nature of the job but are merely related to employees' immigrant background. Workplace inequalities can seriously deteriorate the health and well-being of immigrant employees and are associated with increased burnout scores and a higher risk for sick leave. In light of this, the results of this review were consistent with prior literature (e.g., Jung et al., 2007; Meyer, 2003; Valentín-Cortéz et al., 2020), linking minority stressors with increased psychological distress. We interpret these results to be a confirmation of the thesis that immigrant employees are exposed to minority stress at the workplace, i.e., excess stress experienced by people belonging to marginalized and stigmatized social categories.

The results also show how immigrant employees can deal with various stressors at the workplace, through coping mechanisms such as changing their job or receiving social support from managers. Feeling a sense of belonging and receiving social support from managers and colleagues, in particular, was crucial for fostering a beneficial working environment for immigrant employees. These findings are consistent with the attachment theory, which highlights the relationship between forming emotional bonds and social relations at work and employees' mental health and job satisfaction. Taken together, the perspectives of minority stress and attachment theory increase our understanding of results in this review showing how stressors at the workplace can be dealt with. Although facing the risks of minority stress, immigrant employees can form a work-related resilience that contribute to their overall health and well-being at the workplace, through emotional bonds, social support from coworkers, and managerial support.

Against this background, we would like to highlight the important role of an inclusive and empowering leadership. Managers play a crucial part in creating and preserving a sound, democratic, and inclusive working environment and social climate at the workplace. Our conclusion is underlined by previous research demonstrating how leadership is related to employee health, well-being, job satisfaction, and engagement in the company(Andersen et al., 2019; Kuoppala et al., 2008; Ljungblad et al., 2014; Nielsen et al., 2013; Perko et al., 2016; Swedish Agency for Work Environment Expertise, 2020). Not paying attention to discrimination, social exclusion, and harassment at work shows shortcomings in complying with current Swedish laws and regulations, e.g., the Work Environment Act (1977:1160) and the Discrimination Act (2008:567). The responsibilities of a manager go far beyond making sure that safety regulations are followed, and it is pivotal that the management addresses and takes actions to improve the situation for vulnerable groups that face risks in their physical and psychosocial working environment. Apart from a functioning legal system and necessary supervision mechanisms, an awareness of questions related to the working environment and health of immigrant employees as well as the managerial behaviors related to this should continuously be raised. A manager may through his/her own example and by acting according to and adopting an inclusive leadership behavior inspire others to act and approach each other in inclusive and non-discriminatory ways (Eriksson, 2011).

In addition to the important role of the management, the role of employees' trade unions and functions, such as safety representatives and occupational health care 
services, should be mentioned here. As discussed in the "Introduction" of this paper, the trade union movement has been important when it comes to the inclusion of immigrant workers in the labor market and the narrowing of a rights gap between native and immigrant workers. Nevertheless, as the results of this review demonstrate, a higher awareness of inequalities in minority ethnic group members' working environment is needed, and more active measures to combat these inequalities must be taken before their rights can be implemented in practice.

There are, however, important knowledge gaps here, and more studies are needed to form a deeper understanding and analysis of conditions in the working environment for immigrants in Sweden and the influence of such conditions on their health and well-being. There are, for example, a lack of studies using large-scale data focusing on aspects such as birth country or ethnic background, religion, reason for migration, and length of stay in the destination country. There are also very few studies looking at more beneficial aspects for creating a positive working environment for immigrant employees. More specific information on these dimensions focusing on different groups of immigrants would make it easier to draw conclusions and to propose relevant political and organizational measures.

\section{Limitations and Strengths of the Review}

Since we only searched for original and peer-reviewed studies, we may have missed some important publications (cf. Cooper, 2009), e.g., reports or book chapters. Another disadvantage of the review is that many of the included studies "lump" together immigrants as one single group, and do not provide information about birth country, age, gender, religion, and other important variables that can shed light on diversities in the working environment of immigrants in Sweden. A strength of the review is that we included data from various study types, which although it aggravates the ability to synthesize the findings, also strengthens the general conclusions that are drawn, since these are confirmed by a variety of data sources. Nevertheless, the heterogeneity of the included studies, for instance in regard to their research aims and approaches, makes comparing and analyzing the findings in a more detailed manner complicated, if not impossible. The results of this review must therefore be interpreted with caution and viewed as a general summary and synthesis of the information that is available today about immigrants' working environment in Sweden. Still, we believe that the general conclusions drawn from this review can provide important insights into the conditions that immigrant employees face in their working environment and how these can affect their health and well-being. These insights may be built upon in planning future initiatives and studies focusing on immigrant employees' health and wellbeing at the workplace. 


\section{Appendix 1}

Table 1 List of excluded studies with reason

\begin{tabular}{|c|c|}
\hline Author/title & Reason for exclusion \\
\hline $\begin{array}{l}\text { Bonlokke, J.H., Bang, B., Aasmoe, L., Abdel Rahman, } \\
\text { A.L., Syron, L.N., Andersson, E., Dahlman-Höglund, A., } \\
\text { Lopata, L. \& Jeephay, M. (2019) Exposures and health } \\
\text { effects of bioaerosols in seafood processing workers- } \\
\text { A position statement. Journal of Agromedicine, 24(4): } \\
\text { 441-448, https://doi.org/10.1080/1059924X.2019.16466 } \\
85\end{array}$ & The article is not based on original research \\
\hline $\begin{array}{l}\text { Grossi, G., Soares, J.J.F., Ängeslevä, J., Perski, A. (1999). } \\
\text { Psychosocial correlates of long-term sick-leave among } \\
\text { patients with musculoskeletal pain. Pain, 80: 607-619 }\end{array}$ & $\begin{array}{l}\text { The article does not report data specifi- } \\
\text { cally about the association between work } \\
\text { environment of immigrant workers and } \\
\text { how it is related to the prevalence of sick } \\
\text { leave and pain }\end{array}$ \\
\hline $\begin{array}{l}\text { Hellgren, Z. (2015). Markets, regimes and the role of stake- } \\
\text { holders: Explaining precariousness of migrant domestic/ } \\
\text { care workers in different institutional frameworks. Social } \\
\text { Politics, 22(2): } 220-241\end{array}$ & The article is not based on empirical data \\
\hline $\begin{array}{l}\text { Johansson, B., Helgesson, M., Lundberg, I., Nordquist, T., } \\
\text { Leijon, O., Lindberg, P. \& Vingård, E. (2012). Work and } \\
\text { health among immigrants and native Swedes 1990-2008: } \\
\text { A register-based study on hospitalization for common } \\
\text { potentially work-related disorders, disability pension and } \\
\text { mortality. BMC Public Health, 12: } 845\end{array}$ & $\begin{array}{l}\text { The article reports data about the health } \\
\text { status of immigrants regarding mortality, } \\
\text { disability pension, and hospitalization for } \\
\text { lung, heart, psychiatric, and musculo- } \\
\text { skeletal disorders - but not about the } \\
\text { relationship between these aspects and } \\
\text { work environment issues }\end{array}$ \\
\hline
\end{tabular}




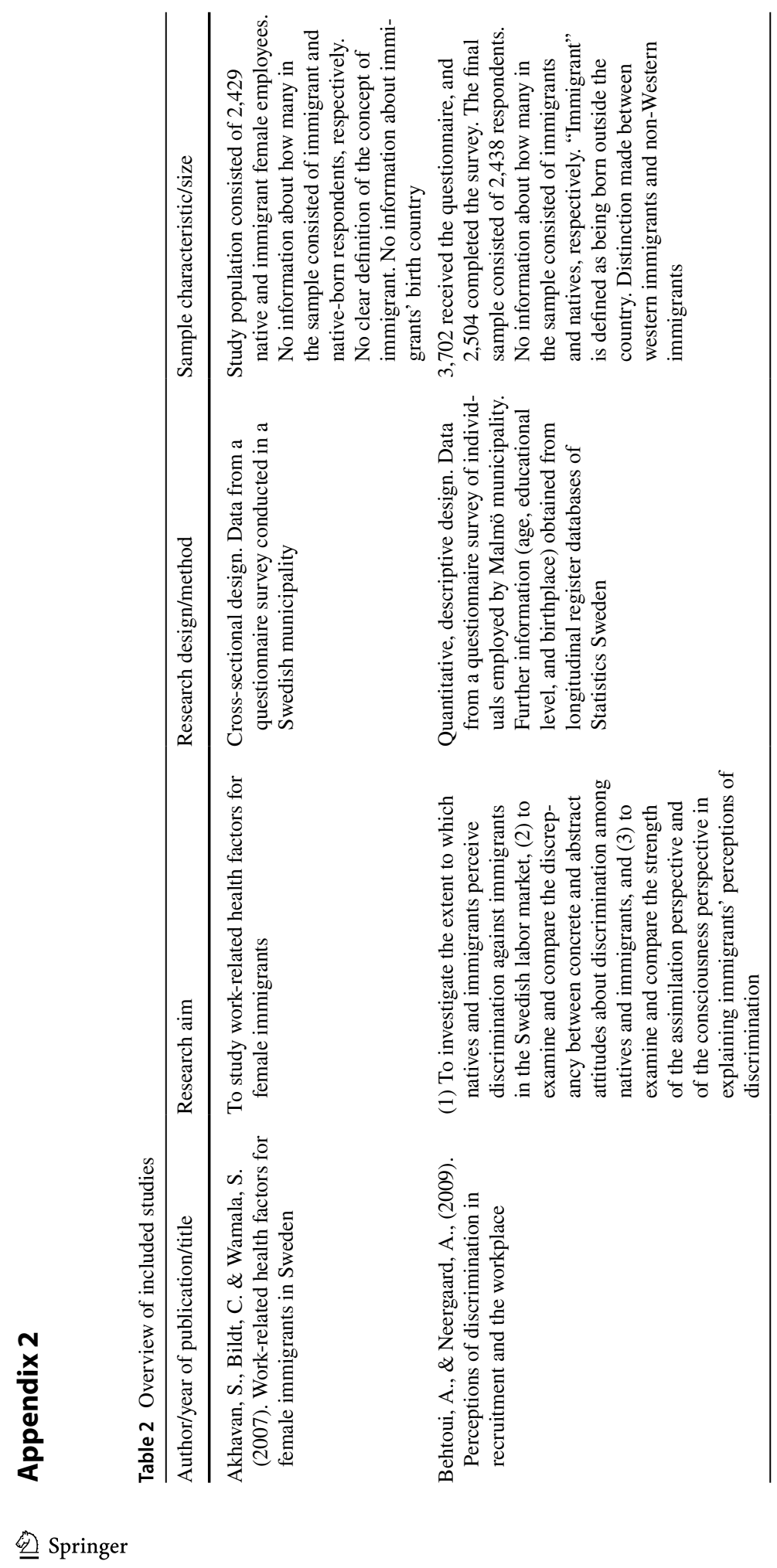




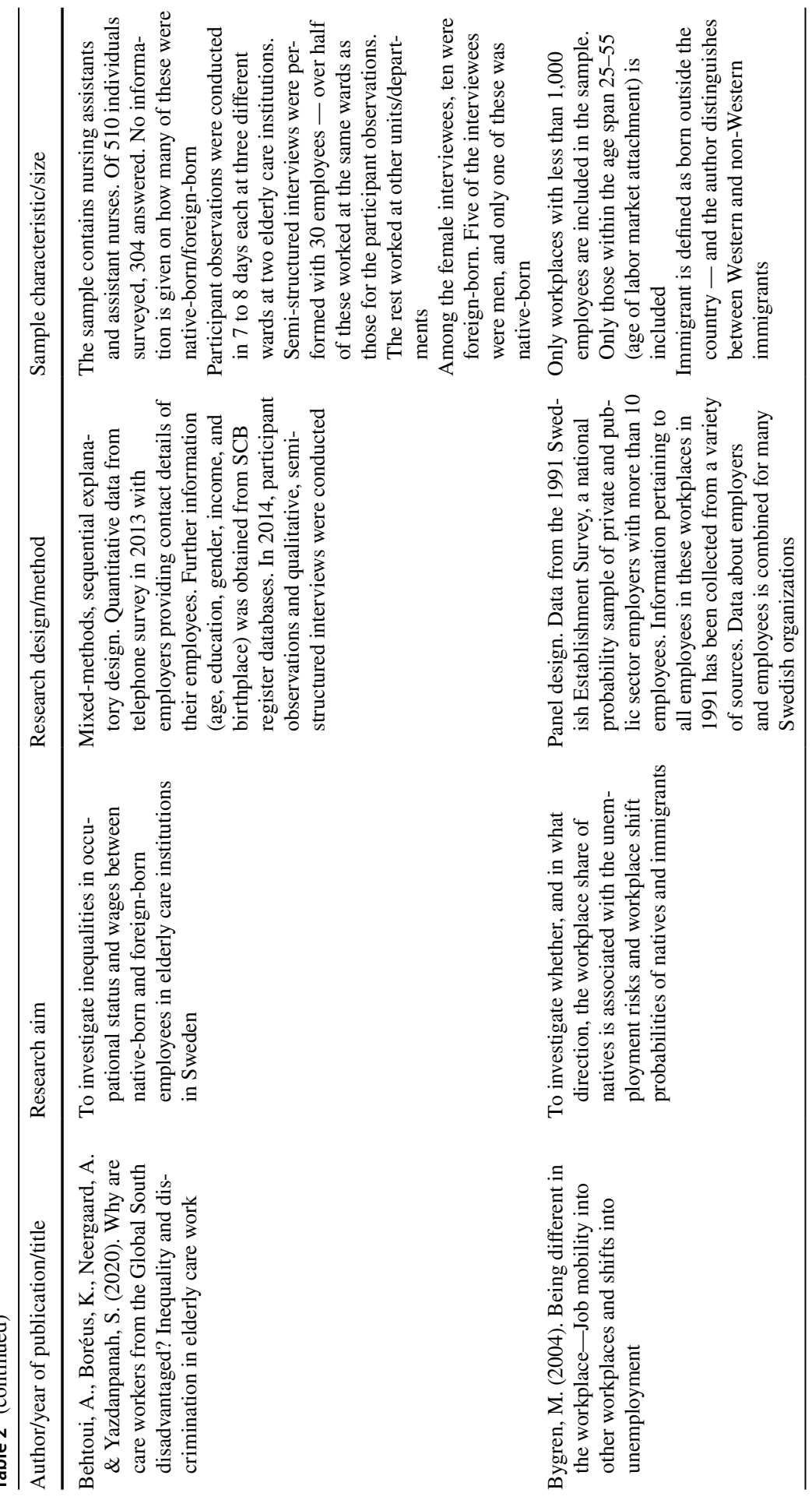




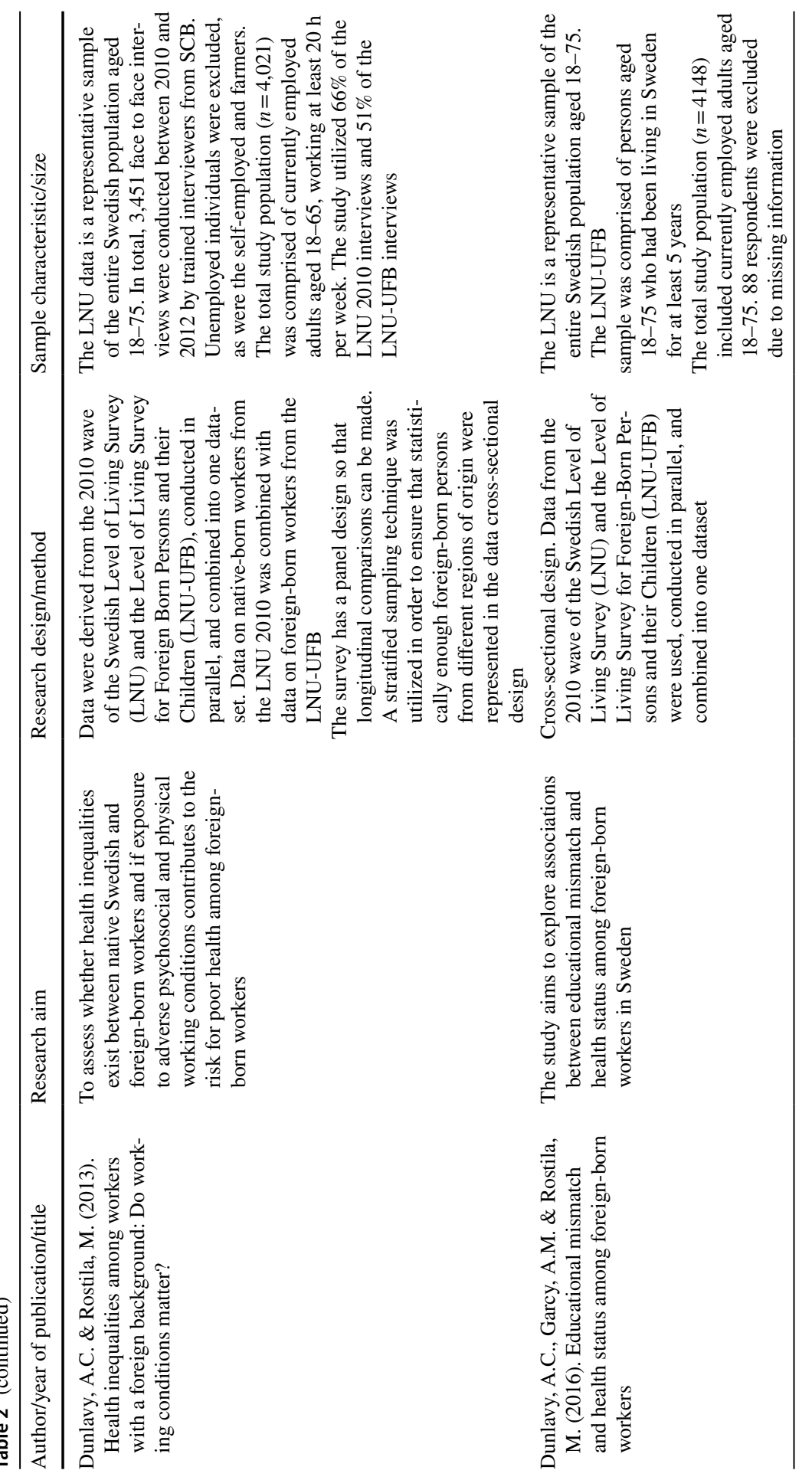




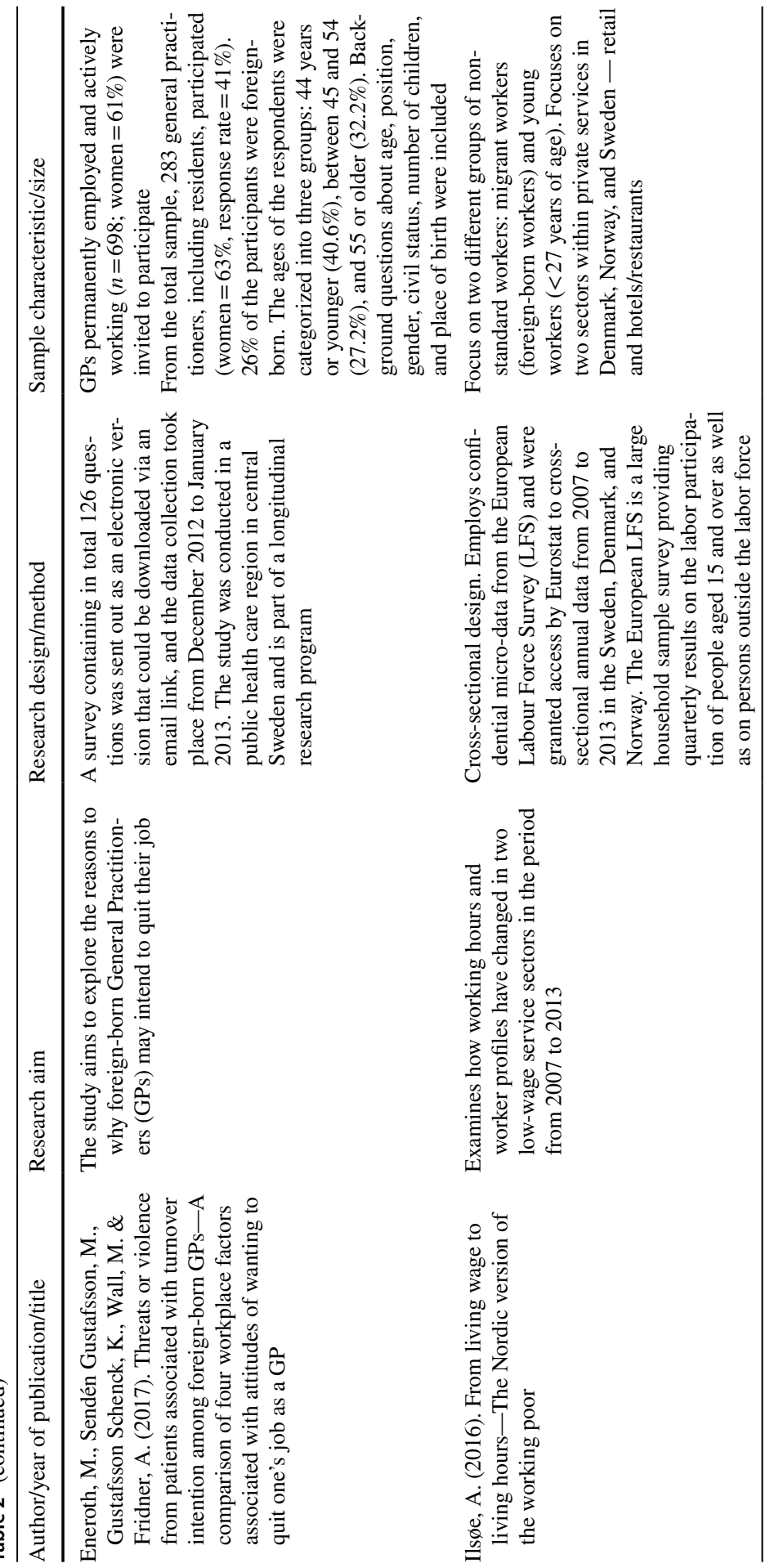




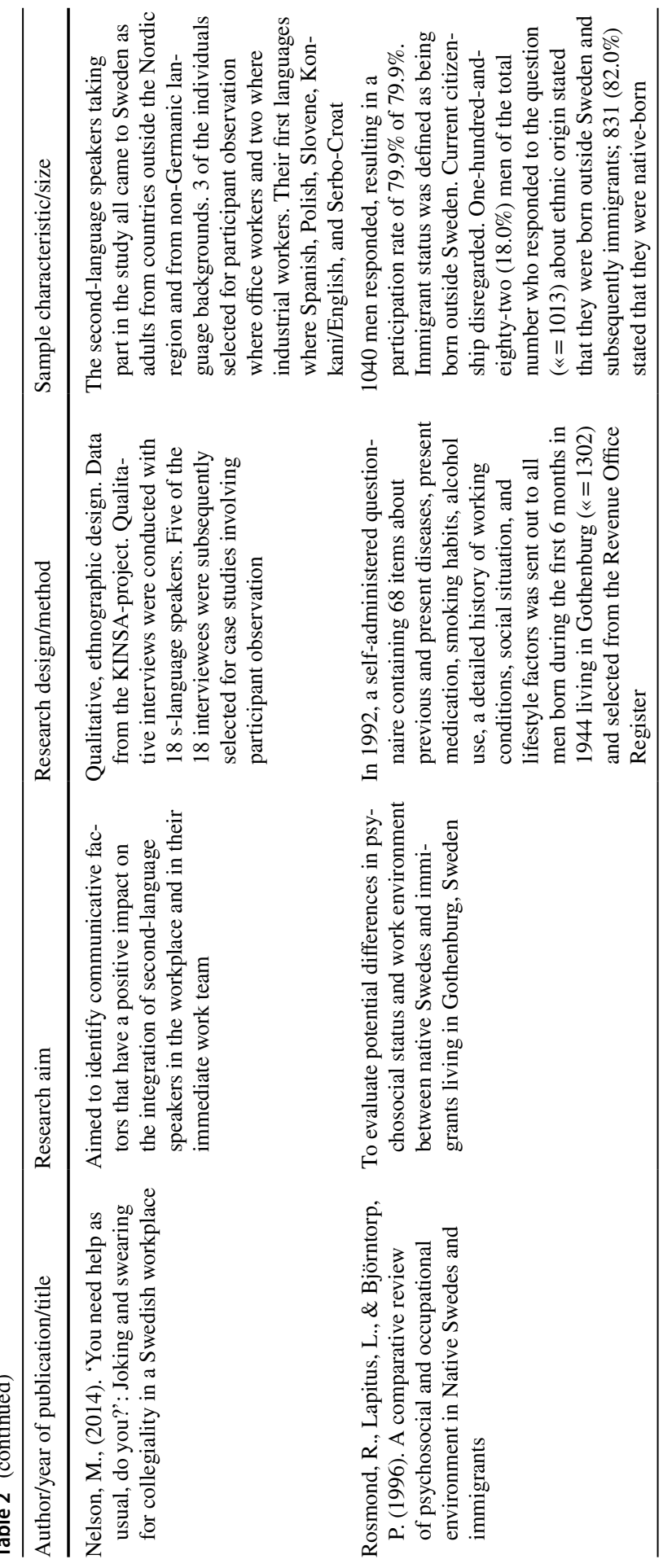




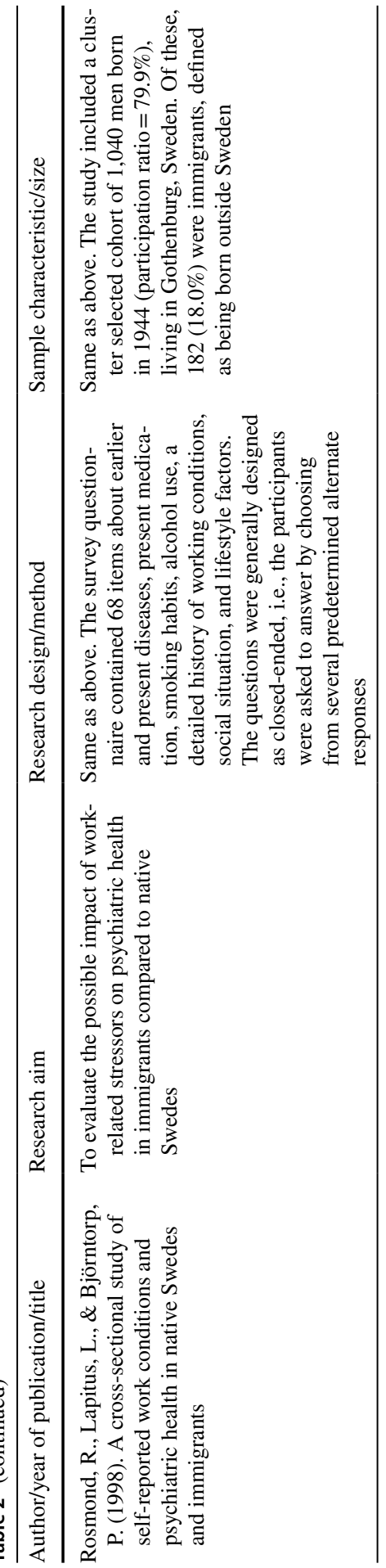




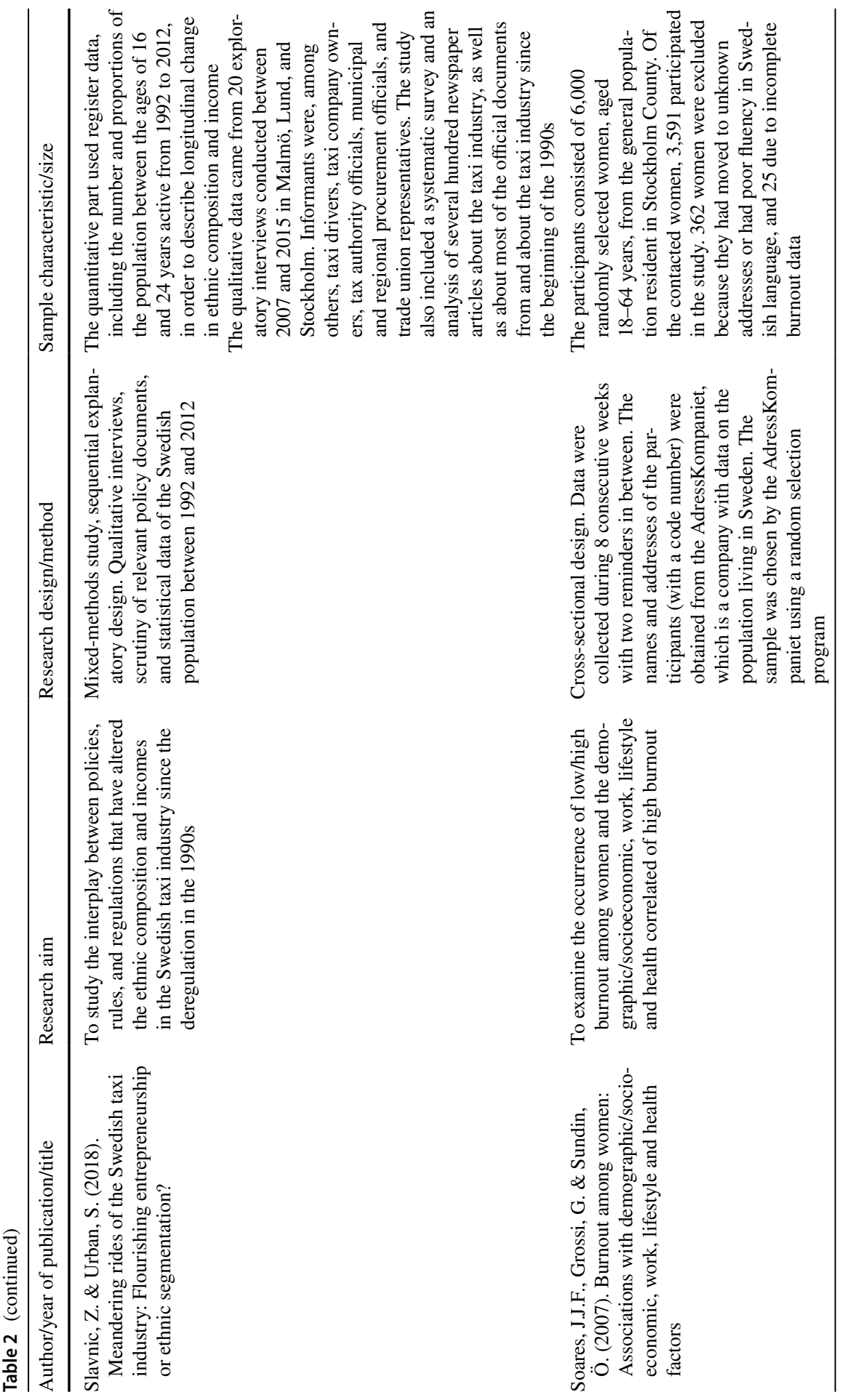




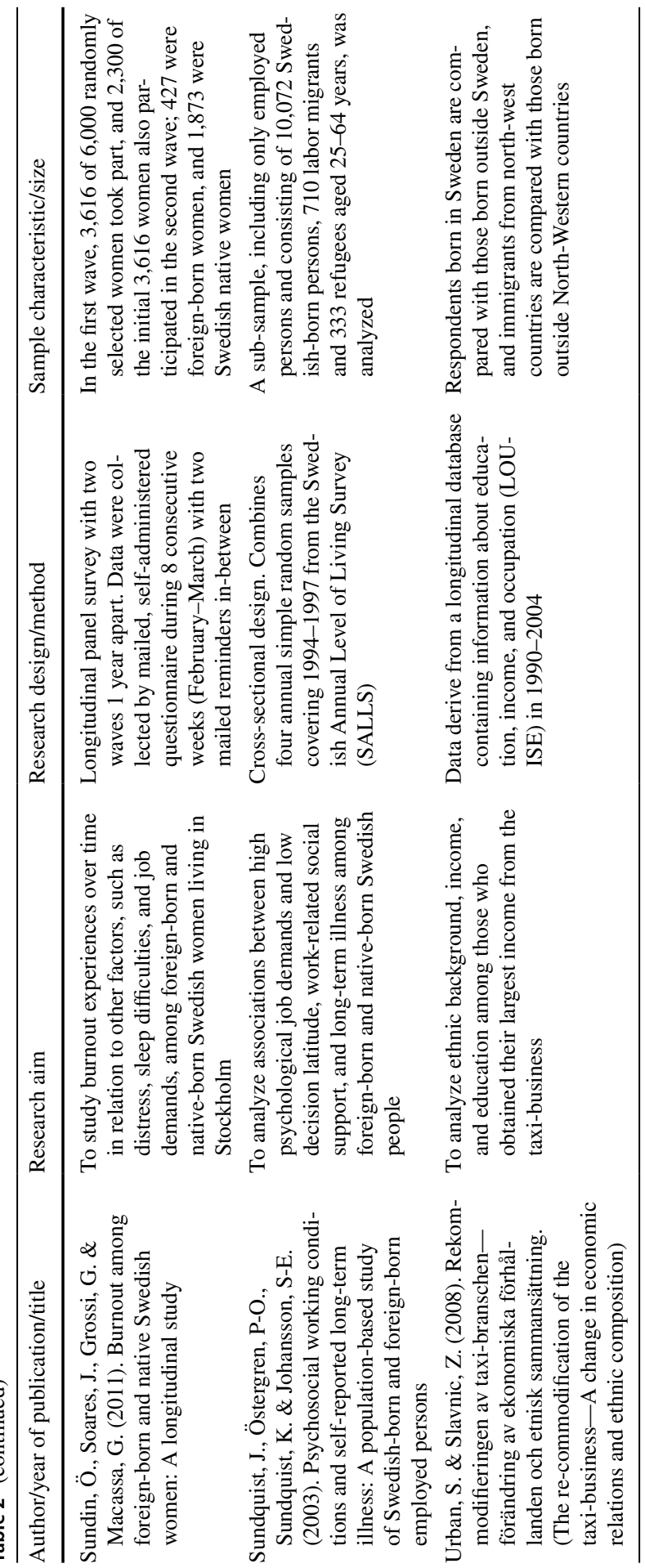




\section{Appendix 3. Quality assessment according to MMAT}

\section{Quantitative descriptive studies}

Screening questions:

1. Is the sampling strategy relevant to address the research question?

2. Is the sample representative of the target population?

3. Are the measurements appropriate?

4. Is the risk of nonresponse bias low?

5. Is the statistical analysis appropriate to answer the research question?

\begin{tabular}{|c|c|c|c|c|c|c|}
\hline Study & Q1: & Q2: & Q3: & Q4: & Q5: & Quality: \\
\hline $\begin{array}{l}\text { Akhavan, S., } \\
\text { Bildt, C. \& } \\
\text { Wamala, } \\
\text { S. (2007). } \\
\text { Work-related } \\
\text { health factors } \\
\text { for female } \\
\text { immigrants } \\
\text { in Sweden }\end{array}$ & Yes & $\begin{array}{l}\text { To a certain } \\
\text { extent }\end{array}$ & $\begin{array}{l}\text { Yes, but } \\
\text { could have } \\
\text { included } \\
\text { other } \\
\text { relevant } \\
\text { measure- } \\
\text { ments }\end{array}$ & Yes & Yes & Medium-high \\
\hline $\begin{array}{l}\text { Bygren, M. } \\
\text { (2004). } \\
\text { Being dif- } \\
\text { ferent in the } \\
\text { workplace- } \\
\text { Job mobility } \\
\text { into other } \\
\text { workplaces } \\
\text { and shifts } \\
\text { into unem- } \\
\text { ployment }\end{array}$ & Yes & Yes & Yes & Yes & Yes & High \\
\hline $\begin{array}{l}\text { Dunlavy, A.C. } \\
\text { \& Rostila, } \\
\text { M. (2013). } \\
\text { Health } \\
\text { inequali- } \\
\text { ties among } \\
\text { workers with } \\
\text { a foreign } \\
\text { background: } \\
\text { Do working } \\
\text { conditions } \\
\text { matter? }\end{array}$ & Yes & $\begin{array}{l}\text { Representative } \\
\text { of native- } \\
\text { born popula- } \\
\text { tion, but only } \\
\text { to a certain } \\
\text { extent of the } \\
\text { immigrant } \\
\text { working } \\
\text { population }\end{array}$ & Yes & $\begin{array}{l}\text { There is a } \\
\text { possibility } \\
\text { of non- } \\
\text { response } \\
\text { bias }\end{array}$ & Yes & Medium \\
\hline
\end{tabular}




\begin{tabular}{|c|c|c|c|c|c|c|}
\hline Study & Q1: & Q2: & Q3: & Q4: & Q5: & Quality: \\
\hline $\begin{array}{l}\text { Dunlavy, A.C., } \\
\text { Garcy, A.M. } \\
\text { \& Rostila, } \\
\text { M. (2016). } \\
\text { Educational } \\
\text { mismatch } \\
\text { and health } \\
\text { status among } \\
\text { foreign-born } \\
\text { workers }\end{array}$ & Yes & Same as above & Yes & Yes & Yes & Medium-high \\
\hline $\begin{array}{l}\text { Eneroth, M., } \\
\text { Sendén } \\
\text { Gustafsson, } \\
\text { M., Gustafs- } \\
\text { son Schenck, } \\
\text { K., Wall, M. } \\
\text { \& Fridner, } \\
\text { A. (2017). } \\
\text { Threats or } \\
\text { violence } \\
\text { from patients } \\
\text { associated } \\
\text { with turnover } \\
\text { intention } \\
\text { among } \\
\text { foreign-born } \\
\text { GPs-A } \\
\text { comparison } \\
\text { of four work- } \\
\text { place factors } \\
\text { associated } \\
\text { with attitudes } \\
\text { of wanting to } \\
\text { quit one's job } \\
\text { as a GP }\end{array}$ & Yes & Yes & $\begin{array}{l}\text { Yes, but } \\
\text { could have } \\
\text { included } \\
\text { more } \\
\text { detailed } \\
\text { measure- } \\
\text { ments for } \\
\text { one variable }\end{array}$ & Yes & Yes & High \\
\hline $\begin{array}{l}\text { Ilsøe, A. } \\
\text { (2016). From } \\
\text { living wage } \\
\text { to living } \\
\text { hours-The } \\
\text { Nordic } \\
\text { version of } \\
\text { the working } \\
\text { poor }\end{array}$ & Yes & Yes & Yes & Yes & Yes & High \\
\hline
\end{tabular}




\begin{tabular}{|c|c|c|c|c|c|c|}
\hline Study & Q1: & Q2: & Q3: & Q4: & Q5: & Quality: \\
\hline $\begin{array}{l}\text { Rosmond, R., } \\
\text { Lapitus, L., } \\
\text { \& Björntorp, } \\
\text { P. (1996). } \\
\text { A compara- } \\
\text { tive review } \\
\text { of psycho- } \\
\text { social and } \\
\text { occupational } \\
\text { environment } \\
\text { in Native } \\
\text { Swedes and } \\
\text { immigrants }\end{array}$ & $\begin{array}{l}\text { Partly. The RQ } \\
\text { deals with } \\
\text { immigrants } \\
\text { generally, but } \\
\text { the sample } \\
\text { only includes } \\
\text { men }\end{array}$ & $\begin{array}{l}\text { Partly. Repre- } \\
\text { sentative to } \\
\text { male native- } \\
\text { born and } \\
\text { immigrant } \\
\text { workers }\end{array}$ & Yes & $\begin{array}{c}\text { There is a } \\
\text { possible } \\
\text { response } \\
\text { bias }\end{array}$ & Yes & Medium \\
\hline $\begin{array}{l}\text { Rosmond, R., } \\
\text { Lapitus, L., } \\
\text { \& Björntorp, } \\
\text { P. (1998). } \\
\text { A cross- } \\
\text { sectional } \\
\text { study of } \\
\text { self-reported } \\
\text { work condi- } \\
\text { tions and } \\
\text { psychiatric } \\
\text { health } \\
\text { in native } \\
\text { Swedes and } \\
\text { immigrants }\end{array}$ & Same as above & Same as above & Yes & $\begin{array}{l}\text { There is a } \\
\text { possible } \\
\text { response } \\
\text { bias }\end{array}$ & Yes & Medium \\
\hline $\begin{array}{l}\text { Soares, J.J.F., } \\
\text { Grossi, G. } \\
\text { \& Sundin, } \\
\text { Ö. (2007). } \\
\text { Burnout } \\
\text { among } \\
\text { women: } \\
\text { Associations } \\
\text { with demo- } \\
\text { graphic/ } \\
\text { socioeco- } \\
\text { nomic, work, } \\
\text { lifestyle and } \\
\text { health factors }\end{array}$ & Yes & $\begin{array}{l}\text { Partly. Since } \\
\text { women with } \\
\text { poor fluency } \\
\text { in Swed- } \\
\text { ish where } \\
\text { excluded, the } \\
\text { sample is not } \\
\text { entirely rep- } \\
\text { resentative } \\
\text { of foreign- } \\
\text { born female } \\
\text { workers }\end{array}$ & Yes & $\begin{array}{l}\text { Yes. High } \\
\text { non- } \\
\text { response } \\
\text { rate and } \\
\text { limited } \\
\text { possibilities } \\
\text { to analyze } \\
\text { differences } \\
\text { between } \\
\text { responders } \\
\text { and non- } \\
\text { responders } \\
\text { - but risk } \\
\text { of bias } \\
\text { seems to be } \\
\text { low }\end{array}$ & Yes & Medium-high \\
\hline
\end{tabular}




\begin{tabular}{|c|c|c|c|c|c|c|}
\hline Study & Q1: & Q2: & Q3: & Q4: & Q5: & Quality: \\
\hline $\begin{array}{l}\text { Sundin, Ö., } \\
\text { Soares, J., } \\
\text { Grossi, G. } \\
\text { \& Macassa, } \\
\text { G. (2011). } \\
\text { Burnout } \\
\text { among } \\
\text { foreign-born } \\
\text { and native } \\
\text { Swedish } \\
\text { women: A } \\
\text { longitudinal } \\
\text { study }\end{array}$ & Yes & $\begin{array}{l}\text { Partly. Only } \\
\text { women in } \\
\text { Stockholm } \\
\text { recruited. } \\
\text { Also, only } \\
\text { foreign-born } \\
\text { women who } \\
\text { were fluent } \\
\text { in Swedish } \\
\text { could answer } \\
\text { the question- } \\
\text { naire }\end{array}$ & Yes & $\begin{array}{l}\text { Yes. High } \\
\text { non- } \\
\text { response } \\
\text { rate, but } \\
\text { low risk of } \\
\text { bias since } \\
\text { responders } \\
\text { and non- } \\
\text { responders } \\
\text { do not differ }\end{array}$ & Yes & Medium-high \\
\hline $\begin{array}{l}\text { Sundquist, } \\
\text { J., Öster- } \\
\text { gren, P-O., } \\
\text { Sundquist, K. } \\
\text { \& Johansson, } \\
\text { S-E. (2003). } \\
\text { Psychosocial } \\
\text { working con- } \\
\text { ditions and } \\
\text { self-reported } \\
\text { long-term } \\
\text { illness: A } \\
\text { population- } \\
\text { based study } \\
\text { of Swedish- } \\
\text { born and } \\
\text { foreign-born } \\
\text { employed } \\
\text { persons }\end{array}$ & Yes & Yes & Yes & Yes & Yes & High \\
\hline $\begin{array}{l}\text { Urban, S. \& } \\
\text { Slavnic, } \\
\text { Z. (2008). } \\
\text { Rekommodi- } \\
\text { fieringen } \\
\text { av taxi- } \\
\text { branschen- } \\
\text { förändring av } \\
\text { ekonomiska } \\
\text { förhållanden } \\
\text { och etnisk } \\
\text { samman- } \\
\text { sättning. } \\
\text { (The re-com- } \\
\text { modification } \\
\text { of the taxi- } \\
\text { business-A } \\
\text { change in } \\
\text { economic } \\
\text { relations and } \\
\text { ethnic com- } \\
\text { position) }\end{array}$ & Yes & Yes & Yes & Can't tell & Yes & Medium-high \\
\hline
\end{tabular}




\begin{tabular}{|c|c|c|c|c|c|c|}
\hline Study & Q1: & Q2: & Q3: & Q4: & Q5: & Quality: \\
\hline $\begin{array}{l}\text { Behtoui, A., \& } \\
\text { Neergaard, } \\
\text { A., (2009). } \\
\text { Perceptions } \\
\text { of discrimi- } \\
\text { nation in } \\
\text { recruitment } \\
\text { and the } \\
\text { workplace }\end{array}$ & Yes & $\begin{array}{l}\text { Yes, but only } \\
\text { for those } \\
\text { employed in } \\
\text { Malmö and } \\
\text { in the public } \\
\text { sector }\end{array}$ & Yes & Yes & Yes & High \\
\hline
\end{tabular}

\section{Qualitative studies}

Screening questions:

1. Is the qualitative approach appropriate to answer the research question?

2. Are the qualitative data collection methods adequate to address the research question?

3. Are the findings adequately derived from the data?

4. Is the interpretation of results sufficiently substantiated by data?

5. Is there coherence between qualitative data sources, collection, analysis and interpretation?

Q1: Q2: Q3: Q4: Q4: Quality:

Nelson, M., (2014). 'You need help as usual, do you?': Joking and Yes Yes Yes Yes Yes High swearing for collegiality in a Swedish workplace

\section{Mixed-methods studies}

Screening questions:

1. Is there an adequate rationale for using a mixed methods design to address the research question?

2. Are the different components of the study effectively integrated to answer the research question?

3. Are the outputs of the integration of qualitative and quantitative components adequately interpreted?

4. Are divergences and inconsistencies between quantitative and qualitative results adequately addressed?

5. Do the different components of the study adhere to the quality criteria of each tradition of the methods involved? 


\begin{tabular}{|c|c|c|c|c|c|c|}
\hline Study & Q1: & Q2: & Q3: & Q4: & Q5: & Quality: \\
\hline $\begin{array}{l}\text { Behtoui, A., Boréus, } \\
\text { K., Neergaard, A. } \\
\text { \& Yazdanpanah, } \\
\text { S. (2020). Why are } \\
\text { care workers from } \\
\text { the Global South } \\
\text { disadvantaged? } \\
\text { Inequality and } \\
\text { discrimination in } \\
\text { elderly care work }\end{array}$ & Yes & Yes & Yes & $\begin{array}{l}\text { No divergencies or } \\
\text { inconsistencies } \\
\text { presented }\end{array}$ & $\begin{array}{l}\text { Yes, but some minor } \\
\text { aspects to consider. } \\
\text { For example, there } \\
\text { is a possible bias in } \\
\text { the case of part-time } \\
\text { positions in the data }\end{array}$ & Medium-high \\
\hline $\begin{array}{l}\text { Slavnic, Z. \& } \\
\text { Urban, S. (2018). } \\
\text { Meandering rides } \\
\text { of the Swedish taxi } \\
\text { industry: Flourish- } \\
\text { ing entrepreneurship } \\
\text { or ethnic segmenta- } \\
\text { tion? }\end{array}$ & Yes & Yes & Yes & Yes & Yes & High \\
\hline
\end{tabular}

Availability of Data and Material Not applicable.

Code Availability Not applicable.

\section{Declarations}

Ethics Approval Not applicable.

Consent to Participate Not applicable.

Consent for Publication Not applicable.

Conflict of Interest The authors declare no competing interests.

Open Access This article is licensed under a Creative Commons Attribution 4.0 International License, which permits use, sharing, adaptation, distribution and reproduction in any medium or format, as long as you give appropriate credit to the original author(s) and the source, provide a link to the Creative Commons licence, and indicate if changes were made. The images or other third party material in this article are included in the article's Creative Commons licence, unless indicated otherwise in a credit line to the material. If material is not included in the article's Creative Commons licence and your intended use is not permitted by statutory regulation or exceeds the permitted use, you will need to obtain permission directly from the copyright holder. To view a copy of this licence, visit http://creativecommons.org/licen ses/by/4.0/.

\section{References}

AFS (2015:4). Organisational and social work environment The Swedish Work Environment Authority provisions on organisational and social work environment, with general recommendations on 
application thereof. Swedish Work Evironment Authority. Retrieved September 12th, 2021 from https://www.av.se/globalassets/filer/publikationer/foreskrifter/engelska/organisational-and-socialwork-environment-afs2015-4.pdf

Akhavan, S., Bildt, C., \& Wamala, S. (2007). Work-related health factors for female immigrants in Sweden. Work, 28(2), 135-143.

Ahonen, E. Q., Benavides, F. G., \& Benach, J. (2007). Immigrant populations, work and health-A systematic literature review. Scandinavian Journal of Work, Environment and Health, 33(2), 96-104.

Andersen, J. H., Malmros, P., Ebbenhoej, N. E., Flachs, E. M., Bengtsen, E., \& Bonde, J. P. (2019). Systematic literature review on the effects of occupational safety and health $(\mathrm{OSH})$ interventions at the workplace. Scandinavian Journal of Work, Environment \& Health, 45(2), 103-113. https://doi.org/ 10.5271/sjweh.3775

Arai, L., Britten, N., Popay, J., Roberts, H., Petticrew, M., Rodgers, M., \& Sowden, A. J. (2007). Testing methodological developments in the conduct of narrative synthesis: A demonstration. Review of Research on the Implementation of Smoke Alarm Interventions, Evidence and Policy, 3, 361-383.

Arbona, C., \& Jimenez, C. (2014). Minority stress, ethnic identity, and depression among Latino/a college students. Journal of Counseling Psychology, 61(1), 162.

Behtoui, A., \& Neergaard, A. (2009). Perceptions of discrimination in recruitment and the workplace. Journal of Immigrant and Refugee Studies, 7(4), 347-369.

Behtoui, A., Boréus, K., Neergaard, A., \& Yazdanpanah, S. (2020). Why are care workers from the global south disadvantaged? Inequality and discrimination in elderly care work. Ethnic and Racial Studies, 43(16), 155-174.

Boräng, F., Kalm, S., \& Lindvall, J. (2020). Unions and the rights of migrants in the long run. Journal of European Social Policy, 30(5), 557-570.

Botha, M., \& Frost, D. M. (2020). Extending the minority stress model to understand mental health problems experienced by the autistic population. Society and Mental Health, 10(1), 20-34.

Bowlby, J. (1982). Attachment and loss: Retrospect and prospect. American Journal of Orthopsychiatry, 52, 664-678.

Bygren, M. (2004). Being different in the workplace: Job mobility into other workplaces and shifts into unemployment. European Sociological Review, 20(3), 199-219.

Canivet, C., Choi, B., Karasek, R., Moghadassi, M., Staland-Nyman, C., \& Östergren, P.-O. (2013). Can high psychological job demands, low decision latitude, and high job strain predict disability pensions? A 12-year follow-up of middle-aged Swedish workers. International Archives of Occupational and Environmental Health, 86, 307-319.

Cooper, H. (2009). Research synthesis and meta-analysis: A step-by-step approach. Sage.

De Vos, J., \& Kirsten, G. J. C. (2015). The nature of workplace bullying experienced by teachers and the biopsychosocial health effects. South African Journal of Education, 35(3), 1-9.

Dunlavy, A. C., \& Rostila, M. (2013). Health inequalities among workers with a foreign background: Do working conditions matter? International Journal of Environmental Research and Public Health, 10, 2871-2887.

Dunlavy, A. C., Garcy, A. M., \& Rostila, M. (2016). Educational mismatch and health status among foreign-born workers. Social Science and Medicine, 154, 36-44.

Dunlavy, A. C., \& Rostila, M. (2017). Arbetsmiljön bland utrikesfödda anställda i Sverige. Arbetsmarknad \& Arbetsliv, 23(1), 46-65.

Ejrnæs, A. (2008). Integration eller isolation? Etniske minoriteter på arbejdsmarkedet. Nyt fra Samfundsvidenskaberne.

Eneroth, M., Sendén Gustafsson, M., Gustafsson Schenck, K., Wall, M., \& Fridner, A. (2017). Threats or violence from patients associated with turnover intention among foreign-born GPs-A comparison of four workplace factors associated with attitudes of wanting to quit one's job as a GP. Scandinavian Journal of Primary Health Care, 35(2), 208-213.

Eriksson, A. (2011). Health-promoting leadership. Doctoral Thesis. Nordic School of Public Health.

Frost, D. M., Lehavot, K., \& Meyer, I. H. (2015). Minority stress and physical health among sexual minority individuals. Journal of Behavioral Medicine, 38(1), 1-8.

Gough, D., Oliver, S., \& Thomas, J. (2012). An introduction to systematic reviews. Sage.

Harden, A., \& Thomas, J. (2005). Methodological issues in combining diverse study types in systematic reviews. International Journal of Social Research Methodology, 8(3), 257-271. https://doi.org/10. 1080/13645570500155078 
Harvey, C., Thompson, S., Otis, E., \& Willis, E. (2020). Nurses' views on workload, care rationing and work environments. Journal of Nursing Management, 28, 912-918. https://doi.org/10.1111/jonm. 13019

Hazan, C., \& Shaver, P. (1990). Love and work: An attachment-theoretical perspective. Journal of Personality and Social Psychology, 59, 270-280.

Hong, Q., Pluye, P., Fàbregues, S., Bartlett, G., Boardman, F., Cargo, M., Dagenais, P., Gagnon, M.-P., Griffiths, F., Nicolau, B., O'Cathain, A., Rousseau, M.-C., Vedel, I. (2018). Mixed Methods Appraisal Tool (MMAT) version 2018: User guide. McGill, 1-11. Retrieved december 3rd 2020 from http://mixedmethodsappraisaltoolpublic.pbworks.com/w/file/fetch/127916259/MMAT_2018_ criteria-manual_2018-08-01_ENG.pdf\%0A

Houkes, I., Janssen, P. P. M., De Jonge, J., \& Bakker, A. B. (2003). Specific determinants of intrinsic work motivation, emotional exhaustion and turnover intention: A multisample longitudinal study. Journal of Occupational and Organizational Psychology, 76, 427-450.

Hudson, D. (2013). Attachment theory and leader-follower relationships. The Psychologist-Manager Journal, 16, 147-159.

Ilsøe, A. (2016). From living wage to living hours-The Nordic version of the working poor. Labour \& Industry: A Journal of the Social and Economic Relations of Work, 26(1), 40-57. https://doi.org/10. 1080/10301763.2016.1152534

Jung, E., Hecht, M. L., \& Wadsworth, B. C. (2007). The role of identity in international students' psychological well-being in the United States: A model of depression level, identity gaps, discrimination, and acculturation. International Journal of Intercultural Relations, 31, 605-624.

Karasek, R. (2008). Low social control and physiological deregulation-The stress-disequilibrium theory, towards a new demand-control model. Scandinavian Journal of Work, Environment \& Health, $34,117-135$.

Karasek, R., \& Theorell, T. (1990). Healthy work. Basic Books.

Knocke, W. (2000). Sweden: Insiders outside the trade union mainstream. In R. Penninx \& J. Roosblad (Eds.), Trade unions, immigration, and immigrants in Europe, 1960-1993 (pp. 157-182). Berghahn Books.

Kuntz, J. R., Malinen, S., \& Näswall, K. (2017). Employee resilience: Directions for resilience development. Consulting Psychology Journal: Practice and Research, 69(3), 223-242.

Kuoppala, J., Lamminpää, A., Liira, J., \& Vainio, H. (2008). Leadership, job well-being, and health effects-A systematic review and a meta-analysis. Journal of Occupational and Environmental Medicine, 50(8), 904-915. https://doi.org/10.1097/JOM.0b013e31817e918d

Lehavot, K., \& Simoni, J. M. (2011). The impact of minority stress on mental health and substance use among sexual minority women. Journal of Consulting and Clinical Psychology, 79(2), 159.

Littman-Ovadia, H., Oren, L., \& Lavy, S. (2013). Attachment and autonomy in the workplace: New insights. Journal of Career Assessment, 21, 502-518.

Ljungblad, C., Granström, F., Dellve, L., \& Åkerlind, I. (2014). Workplace health promotion and working conditions as determinants of employee health. International Journal of Workplace Health Management, 7(2), 89-104. https://doi.org/10.1108/IJWHM-02-2013-0003

Lowe, M. A., Prapanjaroensin, A., Bakitas, M. A., Hites, L., Loan, L. A., Raju, D., \& Patrician, P. A. (2020). An exploratory study of the influence of perceived organizational support, coworker social support, the nursing practice environment, and nurse demographics on burnout in palliative care nurses. Journal of Hospice \& Palliative Nursing, 22(6), 465-547.

Lund, T., Labriola, M., Christensen, K. B., Bültmann, U., \& Villadsen, E. (2006). Physical work environment risk factors for long term sickness absence: Prospective findings among a cohort of 5357 employees in Denmark. BMJ, 332(7539), 449-452.

Kolstrup, C. L. (2012). Work-related musculoskeletal discomfort of dairy farmers and employed workers. Journal of Occupational Medicine and Toxicology, 7(1), 1-9.

Meyer, I. H. (2003). Prejudice, social stress, and mental health in lesbian, gay, and bisexual populations: Conceptual issues and research evidence. Psychological Bulletin, 129, 674-697.

Meyer, R., \& Vasey, H. (2020). Immigration, social networks, and the emergence of ethnic segmentation in a low-skill labor market. Social Science Computer Review, 38(4), 387-404.

Mikulincer, M., Gillath, O., \& Shaver, P. (2002). Activation of the attachment system in adulthood: Threat-related primes increase the accessibility of mental representations of attachment figures. Journal of Personality and Social Psychology, 83, 881-895.

Negi, N. J. (2013). Battling discrimination and social isolation: Psychological distress among Latino day laborers. American Journal of Community Psychology, 51, 164-174. 
Nelson, D. L., \& Quick, J. C. (1991). Social support and newcomer adjustment in organizations: Attachment theory at work? J. Organiz. Behav., 12, 543-554.

Nelson, M. (2014). 'You need help as usual, do you?': Joking and swearing for collegiality in a Swedish workplace. Multilingua, 33(1), 173-200.

Newbold, B. (2009). The short-term health of Canada's new immigrant arrivals: Evidence from LSIC. Ethnicity \& Health, 14(3), 315-336.

Nielsen, M. B., Bergheim, K., \& Eid, J. (2013). Relationships between work environment factors and workers' well-being in the maritime industry. International Maritime Health, 64(2), 80-88.

Nordin, M., \& Rooth, D.-O. (2009). The ethnic employment and income gap in Sweden: Is skill or labour market discrimination the explanation? The Scandinavian Journal of Economics, 111(3), 487-510.

OECD/EU. (2016). Recruiting immigrant workers: Europe: OECD Publishing: Paris. https://doi.org/10. 1787/9789264257290-en

Okechukwu, C. A., Souza, K., Davis, K. D., \& de Castro, A. B. (2014). Discrimination, harassment, abuse, and bullying in the workplace: Contribution of workplace injustice to occupational health disparities. American Journal of Industrial Medicine, 57(5), 573-586. https://doi.org/10.1002/ajim. 22221

Pace, R., Pluye, P., Bartlett, G., Macaulay, A. C., Salsberg, J., Jagosh, J., \& Seller, R. (2012). Testing the reliability and efficiency of the pilot Mixed Methods Appraisal Tool (MMAT) for systematic mixed studies review. International Journal of Nursing Studies, 49(1), 47-53. https://doi.org/10.1016/j. ijnurstu.2011.07.002

Perko, K., Kinnunen, U., Tolvanen, A., \& Feldt, T. (2016). Investigating occupational well-being and leadership from a person-centered longitudinal approach: Congruence of well-being and perceived leadership. European Journal of Work and Organizational Psychology, 25(1), 105-119. https://doi. org/10.1016/j.ssci.2017.05.002

Pien, L.-C., Cheng, Y., \& Cheng, W.-J. (2019). Psychosocial safety climate, workplace violence and selfrated health: A multi-level study among hospital nurses. Journal of Nursing Management, 27, 584591. https://doi.org/10.1111/jonm.12715

Pittman, D. M., Cho Kim, S., Hunter, C. D., \& Obasi, E. M. (2017). The role of minority stress in secondgeneration Black emerging adult college students' high-risk drinking behaviors. Cultural Diversity and Ethnic Minority Psychology, 23(3), 445.

Popay, J., Roberts, H., Sowden, A., Petticrew, Arai, M.L., Britten, N., Rodgers, M., Roen, K. \& Duffy, S. (2006). Guidance on the conduct of narrative synthesis in systematic reviews: Final report. ESRC Methods Programme.

Rasmussen, K., Hansen, C. D., Nielsen, K. J., \& Andersen, J. H. (2011). Incidence of work injuries amongst Danish adolescents and their association with work environment factors. American Journal of Industrial Medicine, 54(2), 143-152.

Rodgers, M., Sowden, A., Petticrew, M., Arai, L., Roberts, H., Britten, N., \& Popay, J. (2009). Testing methodological guidance on the conduct of narrative synthesis in systematic reviews: Effectiveness of interventions to promote smoke alarm ownership and function. Evaluation, 15(1), 49-73.

Rosmond, R., Lapitus, L., \& Björntorp, P. (1996). A comparative review of psychosocial and occupational environment in Native Swedes and immigrants. Scandinavian Journal of Social Medicine, 24(4), 237-242.

Rosmond, R., Lapitus, L., \& Björntorp, P. (1998). A cross-sectional study of self-reported work conditions and psychiatric health in native Swedes and immigrants. Occupational Medicine, 48(5), 309-314.

Rydgren, J. (2004). Mechanisms of exclusion: Ethnic discrimination in the Swedish labour market. Journal of Ethnic and Migration Studies, 30(4), 697-716.

Salvatore, J., \& Shelton, J. N. (2007). Cognitive costs of exposure to racial prejudice. Psychological Science, $18,810-815$.

Saasa, S. K. (2019). Discrimination, coping, and social exclusion among African immigrants in the United States: A moderation analysis. Social Work, 64(3), 198-206.

SBU. (2017). Utvärdering av metoder i hälso-och sjukvården: En handbok. SBU-Statens Beredning för Medicinsk Utvärdering (SBU), 3 uppl, Stockholm. (The Swedish council on health technology assessment in health care. (2017). Evaluation of methods in health care: A handbook. The Swedish Council on Health Technology Assessment in health Care, 3st edition, Stockholm.) Download from https://www.sbu.se/contentassets/d12fd955318f4feab3709d7ebcc9a72b/sbushandbok.pdf 
Schlosser, R. W., Wendt, O., \& Sigafoos, J. (2007). Not all systematic reviews are created equal: Considerations for appraisal. Evidence-Based Communication Assessment and Intervention, 1(3), 138-150. https://doi.org/10.1080/17489530701560831

Schirmer, L., \& Lopez, F. (2001). Probing the social support and work strain relationship among adult workers: Contributions of adult attachment orientations. Journal of Vocational Behavior, 59, 17-33.

Shen, P., \& Slater, P. (2021). The effect of occupational stress and coping strategies on mental health and emotional well-being among university academic staff during the COVID-19 outbreak. International Education Studies, 14(3), 82-95.

Showers, F. (2015). Being black, foreign and woman: African immigrant identities in the United States. Ethnic and Racial Studies, 38, 1815-1830.

Singletary, S. B. (2009). The differential impact of formal and interpersonal discrimination on job performance. (Doctoral dissertation). Rice University. Retrieved from https://scholarship.rice.edu/bitst ream/handle/1911/61816/3362407.PDF?sequence $=1$

Slavnic, Z., \& Urban, S. (2018). Meandering rides of the Swedish taxi industry: Flourishing entrepreneurship or ethnic segmentation? International Journal of Sociology and Social Policy, 38(5), 444-458.

Soares, J. J. F., Grossi, G., \& Sundin, Ö. (2007). Burnout among women: Associations with demographic/ socioeconomic, work, lifestyle and health factors. Archives of Women's Mental Health, 10, 61-71.

SOU. (2006:78). Hälsa, vård och strukturell diskriminering [Health, care and structural discrimination]. Stockholm 2006: Statens offentliga utredningar. [Official reports of the Swedish government].

SOU. (2005:59). Arbetslivets (o)synliga murar. [The (in)visible walls of the working life]. Stockholm 2005: Statens offentliga utredningar. [Official reports of the Swedish government].

SOU. (2006:60) På tröskeln till lönearbete. Diskriminering, exkludering och underordning av personer med utländsk bakgrund. [On the threshold to paid work. Discrimination, exclusion and subordination of individuals of an immigrant background]. Stockholm 2006: Statens offentliga utredningar [Official reports of the Swedish government].

Stansfeld, S., \& Candy, B. (2006). Psychosocial work environment and mental health-A meta-analytic review. Scandinavian Journal of Work, Environment \& Health, 32(6), 443-462.

Statistics Sweden. (2010). Born in Sweden-But still different? The significance of parents' country of birth. SCB.

Statistics Sweden (2019). Arbetskraftsundersökningarna (AKU). Retrieved from https://www.scb.se/ contentassets/9d3fad266baf4bef96321252f80c7710/am0401_2019a01_sm_am12sm2001.pdf

Sterud, T., Tynes, T., Mehlum, I. S., et al. (2018). A systematic review of working conditions and occupational health among immigrants in Europe and Canada. BMC Public Health, 18, 770. https://doi. org/10.1186/s12889-018-5703-3

Sundin, Ö., Soares, J., Grossi, G., \& Macassa, G. (2011). Burnout among foreign-born and native Swedish women: A longitudinal study. Women \& Health, 51(7), 643-660.

Sundquist, J., Östergren, P.-O., Sundquist, K., \& Johansson, S.-E. (2003). Psychosocial working conditions and self-reported long-term illness: A population-based study of Swedish-born and foreignborn employed persons. Ethnicity and Health, 8(4), 307-317.

Svalund, J., \& Berglund, T. (2018). Fixed-term employment in Norway and Sweden: A pathway to labour market marginalization? European Journal of Industrial Relations, 24(3), 261-277.

Svensson, M., Wigerfeldt, A.S., Urinboyev, R., Nilsson, U., Littorin, M., Lundqvist, P., Nyström, B., Westregård, A., Bohgard, M., Alkan-Olsson, J. \& Albin, A. (2015). Migrantarbetare inom jordbruket. Arbetsmiljö och arbetsvillkor. Arbetsliv i omvandling, 1. Retrieved from https://journals.lub. lu.se/aio/article/view/17328/15685

Swedish Agency for Work Environment Expertise. (2020). Leadership for health and wellbeing-A systematic review. Report 2020:5. Retrieved from https://media.sawee.se/2020/06/Leadership-forhealth-and-well-being-\%E2\%80\%93-a-systematic-review.pdf

Takala, J., Urrutia, M., Hämäläinen, P., \& Saarela, K. L. (2009). Global and European work environment-Numbers, trends, and strategies. Scandinavian Journal of Work, Environment \& Health, 7 , $15-23$.

Trygged, S. (2019). A promised land or a paradise lost?: Contemporary challenges for the Swedish welfare state (1st ed.). In: S. Trygged \& E. Righard (eds.)., Inequalities and migration: Challenges for the Swedish welfare state (pp. 15-30). Studentlitteratur AB.

Tziner, A., Ben-David, A., Oren, L., \& Sharoni, G. (2014). Attachment to work, job satisfaction and work centrality. Leadership and Organization Development Journal, 35, 555-565. 
Urban, S., \& Slavnic, Z. (2008). Rekommodifieringen av taxi-branschen-förändring av ekonomiska förhållanden och etnisk sammansättning. (The re-commodification of the taxi-business-A change in economic relations and ethnic composition). Dansk Sociologi, 19(1), 75-94.

Urban, S. (2013). Restaurant work experience as stepping stone to the rest of labour market: Entry to and exit from the restaurant sector among young people of immigrant backgrounds in Sweden. Nordic Journal of Migration Research, 3(2), 100-109.

Valentín-Cortés Valentín-Cortés, M., Benavides, Q., Bryce, R., Rabinowitz, E., Rion, R., Lopez, W. D., \& Fleming, P. J. (2020). Application of the minority stress theory: Understanding the mental health of undocumented Latinx immigrants. American Journal of Community Psychology, 66(3-4), 325-336.

Wang, Z., \& Jing, X. (2018). Job satisfaction among immigrant workers: A review of determinants. Social Inidicators Research, 139, 381-401.

Wang, Q., \& Pandit, K. K. (2007). Measuring ethnic labour market concentration and segmentation. Journal of Ethnic and Migration Studies, 33(8), 1227-1252.

Westerlund, H. et al. (2010). 'Managerial leadership is associated with employee stress, health, and sickness absence independently of the demand-control-support model'. 1 Jan. 71-79.

Wu, C., Parker, S., \& de Jong, J. (2014). Feedback seeking from peers: A positive strategy for insecurely attached team workers. Human Relations Studies; Towards the Integration of the Social Sciences, 67, 441-464.

Yakushko, O., Watson, M., \& Thomspson, S. (2008). Stress and coping in the lives of recent immigrants and refugees: Considerations for counselling. International Journal of Advancement of Counselling, 30, 167-178.

Yip, J., Ehrhardt, K., Black, H., \& Walker, D. O. (2018). Attachment theory at work: A review and directions for future research. Journal of Organizational Behavior, 39(2), 185-198.

Publisher's Note Springer Nature remains neutral with regard to jurisdictional claims in published maps and institutional affiliations.

\section{Authors and Affiliations}

\section{Pinar Aslan Akay ${ }^{1}$ D $\cdot$ Nader Ahmadi $^{1}$}

Nader Ahmadi

Nader.ahmadi@mynak.se

1 The Swedish Agency for Work Environment Expertise, 80006 Gävle, Sweden 